\title{
Can we predict tuberculosis cure? What tools are available?
}

\author{
Delia Goletti ${ }^{1}$, Cecilia S. Lindestam Arlehamn ${ }^{2}$, Thomas J. Scriba ${ }^{3}$, \\ Richard Anthony ${ }^{4}$, Daniela Maria Cirillo ${ }^{5}$, Tonino Alonzi ${ }^{1}$, Claudia M. Denkinger ${ }^{6}$ \\ and Frank Cobelens ${ }^{7}$
}

Affiliations: ${ }^{1}$ Translational Research Unit, National Institute for Infectious Diseases “L. Spallanzani" IRCCS, Dept of Epidemiology and Preclinical Research, Rome, Italy. ${ }^{2}$ Division of Vaccine Discovery, La Jolla Institute for Allergy and Immunology (LJI), La Jolla, CA, USA. ${ }^{3}$ South African Tuberculosis Vaccine Initiative, Institute of Infectious Disease and Molecular Medicine, and Division of Immunology, Dept of Pathology, University of Cape Town, Cape Town, South Africa. ${ }^{4}$ National Institute for Public Health and the Environment (RIVM). Utrecht, The Netherlands. ${ }^{5}$ Emerging Bacterial Pathogens Unit, San Raffaele Scientific Institute, HSR, Division of Immunology and Infectious Diseases Milan, Milan, Italy. ${ }^{6}$ Tuberculosis and Hepatitis Programme, FIND, Geneva, Switzerland. ${ }^{7}$ Dept of Global Health and Amsterdam Institute for Global Health and Development, Academic Medical Center, University of Amsterdam, Amsterdam, The Netherlands.

Correspondence: Delia Goletti, Translational Research Unit, National Institute for Infectious Diseases “L. Spallanzani" IRCCS, Dept of Epidemiology and Preclinical Research, Rome, Italy.

E-mail: delia.goletti@inmi.it

@ERSpublications

In this review we summarise the state of the art with regard to discovery of biomarkers that predict relapse-free cure for pulmonary tuberculosis http://ow.ly/tR3430m2NVQ

Cite this article as: Goletti D, Lindestam Arlehamn CS, Scriba TJ, et al. Can we predict tuberculosis cure? What tools are available? Eur Respir J 2018; 52: 1801089 [https://doi.org/10.1183/13993003.01089-2018].

ABSTRACT Antibiotic treatment of tuberculosis takes $\geqslant 6$ months, putting a major burden on patients and health systems in large parts of the world. Treatment beyond 2 months is needed to prevent tuberculosis relapse by clearing remaining, drug-tolerant Mycobacterium tuberculosis bacilli. However, the majority of patients treated for only 2-3 months will cure without relapse and do not need prolonged treatment. Assays that can identify these patients at an early stage of treatment may significantly help reduce the treatment burden, while a test to identify those patients who will fail treatment may help target host-directed therapies.

In this review we summarise the state of the art with regard to discovery of biomarkers that predict relapse-free cure for pulmonary tuberculosis. Positron emission tomography/computed tomography scanning to measure pulmonary inflammation enhances our understanding of "cure". Several microbiological and immunological markers seem promising; however, they still need a formal validation. In parallel, new research strategies are needed to generate reliable tests. 


\section{Introduction}

Tuberculosis (TB) tops the rankings of major global infectious diseases [1]. Antibiotic treatment of TB takes $\geqslant 6$ months, or longer if there is resistance to rifampicin and isoniazid (multidrug-resistant (MDR)-TB) [2]. In drug-susceptible $\mathrm{TB}$, treatment beyond 2 months is needed to clear remaining drug-tolerant Mycobacterium tuberculosis bacilli [3]. Shortening this continuation phase to $<4$ months has led to relapse in up to $40 \%$ of patients, depending on the drug combination [4]. Long treatment is a considerable burden on patients and health services and elevates risk of nonadherence and noncompletion [5].

Shortening TB treatment is a major research goal [6] and several approaches are being pursued, including increased doses of existing drugs, use of repurposed drugs, development of new drugs and adjunctive host-directed therapies [5]. Trials done in the 1970s showed that a course of streptomycin, rifampicin, isoniazid and pyrazinamide even as short as 2-3 months resulted in relapse rates of $<22 \%$ during the first 18 months after treatment completion [4]. This implies that the majority of patients in which the standard 6-month protocol is effective could be cured with a much shorter treatment. Therefore, there is a major need for biomarkers that predict relapse-free cure to identify patients needing full-course treatment from those who can interrupt it earlier. Such biomarkers would also help to accelerate clinical development by simplifying evaluation of candidate drugs and regimens in phase II trials [6-8]. Similarly, biomarkers that predict progression from latency to active TB can be used in reverse to evaluate the efficacy of a treatment and to identify patients who may relapse, as shown in figure 1 for microbiological assays.

This review summarises the state of the art regarding the discovery of biomarkers that predict relapse-free cure for pulmonary TB.

\section{Cure versus relapse}

Efficacy end-points in clinical trials of TB treatment are generally defined as favourable outcome after $\geqslant 12$ months of scheduled therapy [4]. However, treatment outcomes in routine clinical practice are based on distinction between cure and relapse. Cure is interpreted as "free of disease" at completion of treatment, while its bacteriological basis is not strictly defined. Often, outlined as negative bacteriological sputum testing at end of treatment, cure could mean either two or more negative cultures or two or more negative microscopic smear examinations (table 1) [9]. Notably, compared to culture, smear examination has lower sensitivity and specificity, as it detects nonviable bacilli and nontuberculous mycobacteria; additionally, culture methods differ in their detection limits [10].

Relapse is defined as a recurrent episode of TB disease in a patient declared cured. For many years, relapse was thought to reflect endogenous reactivation of persisting infection with the strain of $M$. tuberculosis that caused the preceding disease episode [11]. However, genotyping studies have shown that TB recurrence can be due to re-infection with a different strain [12] or even with the same strain, the latter more likely in endemic communities, with re-infection becoming more probable with time since cure (figure 1 and table 1) [13].

FIGURE 1 Schematic representation of tuberculosis (TB) treatment, cure and relapse. Relapse reflects clinical resurgence of replicating Mycobacterium tuberculosis bacilli left upon cure.

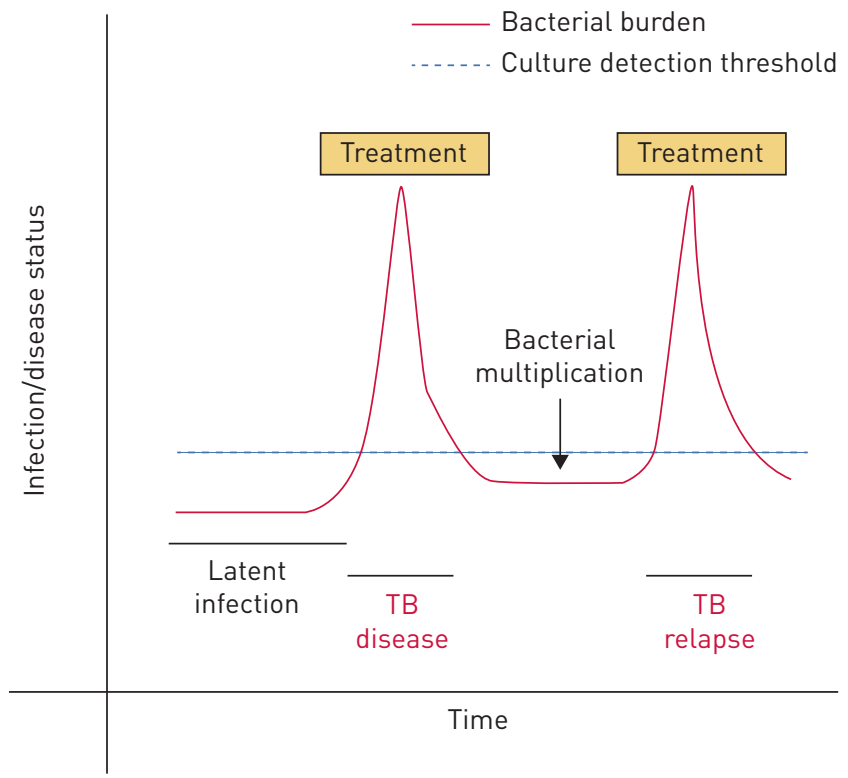


TABLE 1 Definitions of cured tuberculosis (TB), recurrent TB, re-infection and relapse

Cured TB

Recurrent TB disease

Re-infection

Relapse
Smear- or culture-negative sputum specimens in the last month of treatment and on at least one previous occasion, according to WHO guidelines.

Refers to a repeat occurrence of TB disease in a patient that occurs as a result of either relapse or re-infection. Recurrent TB occurs after the previous/initial episode has been classified as clinically cured according to WHO guidelines.

Recurrent TB disease may occur as a result of re-infection, whereby a patient is exogenously infected with a Mycobacterium tuberculosis strain that is either the same or distinct from the organism that caused the original infection.

Defined as a second (or third) episode of active TB disease due to re-emergence of the original infection, as determined by genotypic analysis of the prevailing tubercle bacilli.

WHO: World Health Organization.

Therefore, for the assessment of treatment effects and for the purpose of this review, relapse is interpreted as recurrence with the $M$. tuberculosis strain that was present before treatment.

The relationship between cure and relapse is poorly understood. Different concepts have been applied, often implicitly. One is that cure implies complete removal, through antibiotic killing, of all replicating $M$. tuberculosis, but in some cases with persistence of nonreplicating bacilli that can result in a state of latent TB infection (LTBI) [14]. Relapse then reflects endogenous reactivation of this latent state. Although not proven, this "persistence concept" underlies many mathematical models of TB transmission [15]. An alternative concept is that cure is defined by the threshold of detection by sputum smear examination or culture, and that in some cases $M$. tuberculosis replication remains below that threshold. In this "threshold concept" relapse reflects resurgence of continued $M$. tuberculosis replication and inflammation that was already present at the end of treatment in subclinical or incipient state. The distinction between the two concepts is relevant for how relapse-free cure can be accurately predicted at the end of treatment. In the persistence concept there is a state of latency characterised by nonreplicating bacteria, while in the threshold concept it is highlighted by the presence of an ongoing $M$. tuberculosis replication without the clinical symptoms of active disease. The threshold concept probably best reflects reality, as suggested by recent observations that reported the presence of inflammation in patients defined as "cured". Using combined positron emission tomography (PET) and computed tomography (CT) scanning, which measures pulmonary inflammation through cellular uptake of ${ }^{18} \mathrm{~F}$-labelled fluorodeoxyglucose (FDG), a tracer that reflects glucose metabolism, which is increased in inflammatory areas [16], MALHERBE et al. [17] found that a significant proportion (34\%) of TB patients clinically cured at the end of therapy showed signs of ongoing inflammation. Moreover, the majority of them had detectable $M$. tuberculosis messenger RNA in sputum or bronchoalveolar lavage samples despite negative sputum cultures, thus suggesting that these "cured" patients may not have eradicated all bacilli. In addition, monitoring the activity of tuberculosis treatments in live mice using pulmonary single-photon emission CT, ORDONEz et al. [18] found decreased signs of inflammation, measured as tumour necrosis factor (TNF)- $\alpha$ and interferon (IFN) $-\gamma$ levels, associated to the efficacy of anti-TB treatments. Similar conclusions have been drawn using a cynomolgus macaque model [19]. Notably, it is possible to have ongoing $M$. tuberculosis replication in asymptomatic patients. It has been reported that in high-incidence settings asymptomatic shedding of viable bacilli is frequent [20] and that in HIV-infected patients, positive sputum cultures may be present for up to 12 months before symptomatic, clinically recognisable TB disease occurs [21, 22]. Similar observations have been made in nonhuman primates following low-dose $M$. tuberculosis infection that leads to clinical states ranging from latency to clinical disease. A subset of cynomolgus macaques that were clinically normal, occasionally had positive $M$. tuberculosis cultures from bronchoalveolar lavage or gastric aspirates samples, from several months up to 1 year after infection. Interestingly, some of these cases of subclinical infection showed more gross pathology upon necropsy than persistently culture-negative cases [23]. Importantly, the same authors showed that, upon low-dose M. tuberculosis infection, the animals with latent infection reactivated TB when the action of TNF- $\alpha$ was neutralised, confirming the crucial role of the immune system in controlling infection outcome [24]. Similarly, in the guinea pig model, the use of cortisone induced M. tuberculosis reactivation [25].

Furthermore, a re-analysis of 15 TB treatment trials with 16-24 months post-treatment follow-up showed that $78 \%$ of relapses occurred within 6 months, and $91 \%$ within 12 months after treatment completion [26]. Finally, in a meta-regression of clinical trial data the rate of recurrence was accurately predicted by 2-month sputum culture status and treatment duration, suggesting that the absolute decline in replicating bacilli during the continuation phase of treatment is decisive for relapse-free cure. 
The main argument in favour of the persistence concept comes from long-term follow-up studies showing that relapses may occur after several years [13, 27, 28]. However, these observations have used mainly molecular methods, such as IS6110-RFLP (restriction fragment length polymorphism) or MIRU-VNTR (mycobacterial interspersed repetitive unit-variable-number tandem repeat) methods, which have limited sensitivity for distinguishing closely related but different strains, meaning that re-infection cannot always be absolutely excluded. Conversely, studies using high-resolution methods, such as whole-genome sequencing, found that relapse is very rare beyond 2 years [13]. In addition, re-infection with an identical strain cannot be ruled out. Therefore, these findings strongly question the validity of the persistence concept.

Hereafter, we report the status of the different microbiological, immunological and radiological tests used to evaluate TB cure (table 2).

\section{Microbiological tests to predict relapse-free cure}

Infection with a mycobacterial strain fully sensitive to the standard first-line treatment is one of the strongest predictors of relapse-free cure. Therefore, an accurate bacteriological diagnosis that includes screening for antimicrobial drug resistance remains critical to guide effective TB treatment. Drug resistance is beyond the scope of this review, and hereafter we will assume that the infecting M. tuberculosis strain is fully sensitive.

\section{Sputum smear microscopy}

Sputum smear microscopy has long been used to monitor therapy and early conversion from acid-fast bacilli (AFB) positivity to an AFB-negative status, which is suggestive of successful therapy [29, 30]. Today, smear microscopy is still used to monitor treatment response and remains useful to predict failing therapy and to guide diagnostic and therapeutic interventions, such as extension of the intensive phase after 4 months for patients treated with the "short MDR regimen" [31]. However, in a systematic review, microscopy at 2 months had only low sensitivity and modest specificity for predicting treatment failure or relapse [32]. As standard AFB microscopy detects both viable and nonviable mycobacterial cells, it has been proposed to use selective dyes to detect only metabolically active and potentially replicating bacilli $[33,34]$. However, a proportion of fluorescein diacetate-negative bacteria may still be viable and able to transmit the infection [35].

\section{Mycobacterial culture}

Culture conversion, defined as two independent negative cultures in a patient with positive pretreatment culture, has been proposed as a strong predictor of favourable treatment outcome. Using culture as a predictive marker has several general limitations including poor availability, contamination and turnaround times of weeks to months. Despite these challenges, sputum culture conversion at different

TABLE 2 Available tests to evaluate tuberculosis (TB) cure

Microbiology
Microscopy
Culture
Molecular test
Immunology
Immune cell counts
Immune cell profil

T-cell response
Radiology
Radiography
CT scan
PET/CT scan

AFB conversion from positive to negative $\mathrm{S}$

Negative cultures after 2 and 6 months during TB therapy

Early bactericidal activity (BACTEC-MGIT 960) S

DNA detection (PCR; GeneXpert MTB/RIF test) R

RNA detection (isocitrate lyase mRNA; $M$. tuberculosis rRNA; sets of mRNA signatures) R

$\begin{array}{cc}\text { Monocyte/lymphocyte ratio } & \mathrm{R} \\ \text { CD27 expression of T-cells } & \mathrm{R} \\ \text { CD38/HLA-DR/Ki67 expression of M. tuberculosis-specific T-cells } & \mathrm{R} \\ \text { M-MDSC } & \mathrm{R} \\ \text { IGRA (megapools of peptides; HBHA; ESAT-6; CFP-10) } & \mathrm{R} \\ \text { Levels of inflammatory molecules (IP-10; CRP; } \beta_{2} \text {-microglobulin; a seven-molecule signature) } & \mathrm{R}\end{array}$

CT: computed tomography; PET: positron emission tomography; AFB: acid-fast bacilli; S: standard; R: research; M-MDSC: monocytic myeloid-derived suppressor cells; IP: interferon- $\gamma$ induced protein; CRP: C-reactive protein; IGRA: interferon- $\gamma$ release assay; HBHA: heparin-binding haemagglutinin; ESAT: early-secreted antigenic target; CFP: culture filtrate protein. 
time points is typically used as a microbiological end-point in clinical trials assuming that results from cultures inoculated at 8 weeks from treatment initiation predict treatment outcome. WALLis et al. [36] showed that across studies, month 2 culture status predicted relapse-free cure and predicted recurrence rates (correlation coefficient $\mathrm{R}^{2}=0.86 ; \mathrm{R}^{2}=1$ reflecting perfect prediction). Culture positivity at 2 months has been interpreted as a risk factor for relapse. Others have cautioned that the appropriate culture time could be linked to the drugs in use [37]. However, a high variability in the performance of either 2 or 3 months culture conversion on solid media have been reported. Month 2 culture conversion performed as a reliable surrogate for poor outcome in trials conducted in Hong Kong $\left(\mathrm{R}^{2}=0.86\right)$, but performed poorly in East Africa $\left(R^{2}=0.19\right)$; interestingly, cultures at 3 months showed opposite results $\left(R^{2}=0.62\right.$ and 0.81 , respectively) [38]. Kurbatova et al. [39] showed an association between the median time to culture conversion and outcome in MDR-TB patients (HIV-uninfected or unknown) that was stronger at 6 months with a 14-fold increased probability of successful outcome. These findings have been confirmed by a study on MDR-TB patients in China: sputum culture conversion at 2 months was not statistically associated with treatment success, whereas patients with sputum culture conversion at 3,6 and 24 months had a significantly higher likelihood of success [40].

In this view, rapid measurement of drug-sensitive $M$. tuberculosis growth could be important to predict the effectiveness of the treatments in active TB patients. To this end, the most widely available rapid, fully automated, high capacity, nonradiometric and noninvasive quantitative liquid-based culture method is the BACTEC MGIT (mycobacteria growth indicator tube) 960 system [41]. Although this system is mainly successfully applied for antibiotic susceptibility testing of MDR M. tuberculosis strains, it could be also useful in shortening the time of diagnosis of culture conversion, and hence used to predict therapeutic efficacy.

While multiple negative cultures at the end of treatment are widely used to define treatment success, attempts to use month 2 culture conversion to predict cure and to select patients requiring shorter treatment have resulted in unacceptable relapse rates. In a trial among patients with negative cultures at 2 months of standard first-line treatment that randomised these patients after 4 months to either stop or continue treatment until 6 months, 13 patients in the 4-month arm relapsed compared with three subjects in the 6-month arm ( 7.0 versus $1.6 \%)$; the trial was interrupted by the safety monitoring committee [42].

The early bactericidal activity (EBA) of drugs has been monitored in detail by repeated quantitative cultures during treatment [43]. Although too labour-intensive to be used in routine practice, EBA studies have played an important role in the development of new treatment regimens [44, 45]. Results from these studies have demonstrated that an initial rapid killing rate is generally associated with a successful outcome [46]. After this initial rapid drop in bacterial numbers, a much slower rate of killing by EBA is observed in later stages of treatment. This biphasic killing has been modelled and it is consistent with two populations of bacteria: one which is fully sensitive to most antimicrobials, and one which is more drug tolerant $[47,48]$. Targeting both populations of bacteria appears to be critical to ensure cure. An analysis of serial culture data available from multiple trials concluded that the trend of culture positivity over time is likely to be a better predictive marker of outcome than culture conversion at a single time point [38].

\section{Molecular assays}

Current commercial molecular assays based on mycobacterial DNA detection do not distinguish dead from culturable bacteria and cannot be used for early monitoring of treatment outcome [49]. Мготто and co-workers adapted assays aiming to overcome this limitation. Pretreatment of samples with compounds that fragment free DNA prior to the PCR step has improved early monitoring of TB treatment $[50,51]$.

Measuring bacterial RNA rather than DNA allows viable $M$. tuberculosis cells to be targeted. The detection of isocitrate lyase mRNA correlated highly with colony-forming units in sputum prior to therapy and to time to positivity in liquid culture [52]. An alternative assay targeting more stable ribosomal RNA has been proposed for monitoring bacterial load [53] and reported to be as sensitive as solid culture for monitoring the early bactericidal effect of treatment [54].

Cycle threshold (Ct) values from the GeneXpert MTB/RIF (Xpert) test, a highly standardised PCR assay, have been studied as a possible predictor of cure. Among HIV-negative pulmonary TB patients tested at baseline and at different time points during treatment, the measure of cycle thresholds and relative changes in $\mathrm{Ct}$ values $(\Delta \mathrm{Ct})$ correlated with culture conversion, predicted treatment failure with $75 \%$ sensitivity and $89 \%$ specificity [55]. In a multicentre trial of rifapentine-based treatment of smear-positive $\mathrm{TB}$, modelling of longitudinal Xpert Ct values (measured at weeks 0, 2, 4, 6, 8 and 12) in relation to drug exposure showed higher $\Delta \mathrm{Ct}$ in subjects receiving rifapentine than in subjects receiving standard-dose rifampin, indicating the potential of Xpert $\Delta \mathrm{Cts}$ as a dynamic measure of response to therapy [56]. 
In contrast to the methods based on $M$. tuberculosis culture, one of the main advantages of molecular assays is the possibility to obtain results on the same day of testing. However, although most patients will become negative for standard diagnostic assays in the final phase of their treatment, a low positive score may still be detected in some sensitive molecular tests and may be related to the initial bacillary load. The use of highly sensitive assay such as the new Xpert ULTRA may further increase the number of patients with detection of "trace" (or very low) amounts of M. tuberculosis DNA at the end of treatment [57]. RNA-based assays are promising; however, their implementation under programmatic conditions is challenging. Similarly, the use of $\Delta$ Cts from baseline seems promising, but more data are needed to assess if they have any real value in predicting outcome.

\section{Immunological tools to predict relapse-free cure}

Since the immune responses that regulate protection or pathogenesis of $M$. tuberculosis are not fully elucidated, the understanding of those mechanisms is essential for the identification of diagnostic and/or prognostic markers for successful treatment. To this aim, phenotypic and functional characterisation of T-cells has been undertaken.

\section{T-cell markers}

Markers of T-cell activation and/or differentiation can discriminate between distinct clinical presentations of TB infection/disease. T-lymphocytes pass through several stages of antigen-driven differentiation (early, late and terminally differentiated effector cells) that are characterised by a set of cell surface markers, which may serve as indicators of $M$. tuberculosis replication or antigen load.

T-cell expression of CD27 has been suggested as a good biomarker for the identification of TB infection state. CD27, a member of the TNF receptor superfamily, is constitutively expressed by naïve and early effector T-cells, but is downregulated during later stages of effector T-cell differentiation. Therefore, late effector T-cells exhibit low to no CD27 expression $[58,59]$. Several studies have demonstrated that significantly higher proportions of $M$. tuberculosis-specific IFN- $\gamma$-producing $\mathrm{CD}^{+}{ }^{+}$-cells do not express CD27 (CD27- IFN- $\left.\gamma^{+} \mathrm{CD}^{+}\right)$in persons with active TB disease when compared with healthy controls or cured TB patients [60-66]. In addition, it has been shown that frequencies of CD27 $7^{-}$IFN- $\gamma^{+} \mathrm{CD}^{+}$cells strongly correlate with the degree of lung pathology and matrix destruction [67,68], providing a good biomarker of TB treatment success $[63,69]$. The accuracy of assays based on the modulation of CD27 may be increased by combining several tests based on CD27 or cytokine expression [70]; however, further studies are needed to confirm better accuracy compared to IFN- $\gamma$ release assays (IGRAs).

T-cell activation markers such as CD38, human leukocyte antigen (HLA)-DR and Ki67 also appear to be promising biomarkers of TB. Human CD38, a transmembrane glycoprotein with ectoenzyme properties, is expressed by several immune cell types [71, 72]. HLA-DR is the cell-surface receptor that mediates presentation of antigens via the major histocompatibility complex (MHC) class II pathway to CD4 T-cells [73]. Both are early immune markers, expression of which is upregulated upon T-cell activation in response to microbial infection or vaccination. Ki-67 is a nuclear protein widely used as an intracellular proliferation marker for its selective expression in cycling cells [74]. High levels of CD38, HLA-DR and intracellular Ki67 expression by M. tuberculosis-specific CD4 T-cells were recently shown to be promising biomarkers of active TB disease in HIV-uninfected [66, 75, 76] and HIV-infected persons [76]. Decreased expression of these three markers by $M$. tuberculosis-specific CD4 T-cells was associated with responsiveness to anti-TB treatment and clinical resolution [66, 75]. A limitation of TB biomarkers expressed by $M$. tuberculosis-specific T-cells, such CD38, HLA-DR and Ki67, is that they can only be measured in those with detectable M. tuberculosis-specific T-cell responses. Thus, while the works that report these biomarkers have demonstrated high statistical accuracy [75, 76], it must be considered that some individuals cannot be included in these analyses because of undetectable T-cell responses $[66,75,76]$.

\section{T-cell responses}

The complex mechanisms of antigen presentation and epitope recognition by T-cells make it difficult to design T-cell-based diagnostic tests that are universally applicable to all individuals in a given population (table 3).

Most of the studies that evaluate mycobacterial immune response during TB treatment are based on IGRAs. Using commercial assays (i.e. QuantiFERON TB Gold in-tube (QFT-GIT) and the T-SPOT.TB), variable results of anti-TB therapy effects on $M$. tuberculosis-specific immune responses have been reported. The majority of the studies showed no significant differences in IFN- $\gamma$ levels between the time of TB diagnosis and after clinical cure [77-79]. However, other studies, which used either IGRAs or other immunological tests, have shown decreased or absent responses after cure, while yet others reported increased or persistent responses during and after treatment (up to 12 months post-diagnosis) [80-85]. An 
interesting alternative approach has been proposed for the T-SPOT.TB assay, which measures the ratio between $M$. tuberculosis-specific antigens (TBAg) (i.e. early secreted antigenic target (ESAT)- 6 or culture filtrate protein (CFP)-10) and phytohaemagglutinin (PHA) spot-forming cells. The authors found that the TBAg/PHA ratios were significantly higher either in active TB patients than in LTBI individuals in pulmonary TB [86] or in patients with extrapulmonary TB with respect to pulmonary TB patients [87]. Interestingly, they also found that the TBAg/PHA ratios decrease during anti-TB treatment, thus suggesting that this method could be tested also for monitoring therapeutic efficacy [87].

Several studies have shown that the T-cell response to antigens may differ depending on the antigen (or mycobacterial) load [75, 80, 88-91] and on the availability of antigen at the time of infection [92].

QFT-GIT and T-SPOT.TB assays use peptides of ESAT-6, CFP-10 and TB7.7 for QFT-GIT, to stimulate IFN- $\gamma$-producing T-cells. It has been reported that in $M$. tuberculosis-infected mice ESAT- 6 is produced at high levels during active $M$. tuberculosis growth and the immune response to ESAT- 6 is stable throughout the stages of infection [92-95]. Furthermore, responses to multi-epitopic peptides of ESAT-6 and CFP-10 associate with active $M$. tuberculosis replication in humans [80, 96-99]. These responses are mediated by CD4 T-cells with an effector memory phenotype [77]. Importantly, such responses decrease or are lost after antibiotic treatment of either active TB or LTBI [80]. However, persisting memory responses to these antigens can be detected by long-term in vitro stimulation that allows expansion of the central memory cells [77].

Other antigens have been used for measuring the anti-TB response, such as the heparin-binding haemagglutinin (HBHA), which is expressed at the surface of a variety of mycobacterial species promoting binding to host epithelial cells, pathogenicity and extrapulmonary dissemination of the bacteria [100]. LTBI and cured TB patients are characterised by high IFN- $\gamma$ responses to HBHA compared to individuals with active disease suggesting, therefore, a protective role for the HBHA-specific responses [101-104].

Interestingly, it has been proposed that LTBI patients, which may include subjects with spontaneous sterilisation, quiescent or persistent asymptomatic infection [105-107], could be stratified based on their IFN- $\gamma$ responses to two different mycobacterial antigens; HBHA, associated to latency and ESAT-6, associated to active replication [108].

The choice of the M. tuberculosis antigen could be fundamental for obtaining an accurate measurement of T-cell responses and, therefore, a reliable diagnostic/prognostic value of a specific assay. Beside M. tuberculosis, nontuberculous mycobacteria (NTMs) often found in soil and water reservoirs [109-113] can be, in particular situations, opportunistic pathogens of humans and animal species [114-116]. In fact, some M. tuberculosis-derived epitopes have been shown to be hyperconserved among the genomes of the M. tuberculosis complex [117] and, additionally, a large proportion of epitopes are conserved across other species of the Mycobacteria [118]. Environmental exposure to NTMs and cross-reactive immune responses can influence resistance to $M$. tuberculosis, interfere with or enhance protective responses to vaccination and may contribute to the variation in efficacy observed with bacille Calmette-Guerin vaccination [119-121].

A possible approach to overcome the challenges of promiscuity, ethnic diversity and a highly heterogeneous M. tuberculosis-specific response [122] is the use of peptide "megapools" that comprise dozens to hundreds of peptides that collectively trigger T-cell responses in virtually every individual [123]. TB treatment may preferentially affect immune responses to some $M$. tuberculosis antigens, and not others, as well as affecting the microbiome composition in an immunologically relevant manner [105, 124, 125]. Moreover, even if the frequency of T-cells recognising each individual epitope may be below the limit of detection, a large number of epitopes might allow detection of sufficient responding T-cells to pass this limitation, which could be relevant, for instance, in the evaluation of T-cell phenotypic markers, as briefly discussed earlier $[66,75,76]$.

In addition, efforts have been made to study CD8 T-cells in TB-infected humans. M. tuberculosis-specific CD8 T-cell responses are more frequently detected in active TB compared to LTBI $[88,90,126,127]$. Moreover, M. tuberculosis-specific CD8 T-cells have been associated with recent exposure to TB [128] and decline upon anti-TB treatment [88]. Furthermore, it has been shown that the patients with pulmonary TB that will subsequently relapse exhibit, at the time of diagnosis, excessively robust cytolytic responses to live M. tuberculosis, in vitro, compared with that of patients who will achieve durable cure [129]. An updated version of the QFT-GIT assay termed QuantiFERON TB Plus (QFT-P) [130, 131], includes an additional antigen tube (TB2), which contains peptides stimulating M. tuberculosis-specific CD8 T-cells, in addition to the CD4 T-cell response detected with QFT-GIT [78, 132]. IFN- $\gamma$ responses measured by the TB2 tube have been observed in active TB patients $[78,132]$, and significantly decrease after cure when compared to baseline [133]. Although promising, further research is needed to establish the efficacy of this new assay as marker for treatment monitoring and/or outcome. 
TABLE 3 Markers evaluated as potential tests for tuberculosis (TB) cure

\begin{tabular}{|c|c|c|c|c|c|c|c|}
\hline & \multirow[t]{2}{*}{$\begin{array}{c}\text { Description of the } \\
\text { test }\end{array}$} & \multirow[t]{2}{*}{ Biomarker } & \multicolumn{3}{|c|}{ Method of evaluation of TB cure } & \multicolumn{2}{|c|}{$\begin{array}{l}\text { Time of TB cure } \\
\text { evaluated if different } \\
\text { from end of therapy }\end{array}$} \\
\hline & & & $\begin{array}{l}\text { Clinical } \\
\text { outcome }\end{array}$ & $\begin{array}{l}\text { Microbiological } \\
\text { tools }\end{array}$ & $\begin{array}{l}\text { Chest } \\
\text { radiography }\end{array}$ & $\begin{array}{c}\text { Not } \\
\text { indicated }\end{array}$ & $\begin{array}{l}\text { During } \\
\text { treatment }\end{array}$ \\
\hline \multirow[t]{6}{*}{ Immune markers } & $\begin{array}{l}\text { Commercial tests } \\
\text { for LTBI diagnosis }\end{array}$ & $\begin{array}{c}\text { QFT-Plus } \\
\text { QFT-GIT, T-SPOT.TB }\end{array}$ & [133] & {$[78,86,87,133]$} & [133] & & \\
\hline & Blood cell counts & $\begin{array}{l}\text { Decreased monocyte/ } \\
\text { lymphocyte ratio }\end{array}$ & & [141] & & & \\
\hline & $\begin{array}{c}\text { Cell differentiation } \\
\text { markers }\end{array}$ & $\begin{array}{l}\text { Upmodulation of CD27 in } \\
\text { CD4 T-cells }\end{array}$ & {$[63,65]$} & [62] & [65] & [66] & \\
\hline & & $\begin{array}{c}\text { Markers of lung tissue } \\
\text { repair (platelet activity VEGF, } \\
\text { TGF- } \beta, \text { MMPs) }\end{array}$ & & {$[195,196]$} & & {$[172,173]$} & {$[175,198]$} \\
\hline & $\begin{array}{l}\text { Responses to RD1 } \\
\text { or latency } \\
\text { antigens }\end{array}$ & $\begin{array}{c}\text { IFN- } \gamma \text { response to TB } \\
\text { antigens }\end{array}$ & & [101] & & [88] & \\
\hline & Molecular tests & $\begin{array}{c}\text { Decreased expression } \\
\text { signatures of IFN response } \\
\text { and T-cell genes or cytolytic } \\
\text { response }\end{array}$ & {$[184]$} & & & $\begin{array}{c}{[129,177} \\
199]\end{array}$ & \\
\hline \multirow[t]{5}{*}{$\begin{array}{l}\text { Microbiology } \\
\text { tests }\end{array}$} & Staining & $\begin{array}{l}\text { Smear at month } 2 \\
\text { post-culture }\end{array}$ & & {$[31,33,35]$} & & [34] & \\
\hline & Culture & $\begin{array}{l}\text { Culture at month } 2 \\
\text { post-culture }\end{array}$ & & {$[37,39,40,42]$} & & & {$[50]$} \\
\hline & Molecular tests & $\begin{array}{l}\text { Targeting DNA } \\
\text { (M. tuberculosis) }\end{array}$ & & $\begin{array}{c}{[49,51,53,55,} \\
57]\end{array}$ & & [56] & \\
\hline & & $\begin{array}{l}\text { Targeting RNA } \\
\text { (M. tuberculosis) }\end{array}$ & & {$[17]$} & & & $\begin{array}{c}{[52,54,} \\
200]\end{array}$ \\
\hline & & TB antigens & & & & [136] & \\
\hline
\end{tabular}

LTBI: latent TB infection; IFN: interferon; IP: IFN- $\gamma$-induced protein; CRP: C-reactive protein; IL: interleukin; TNF: tumour necrosis factor; VEGF: vascular endothelial growth factor; TGF: transforming growth factor; MMP: matrix metalloproteinase; RD: region of deletion; PET: positron emission tomography; CT: computed tomography; M. tuberculosis: Mycobacterium tuberculosis. 


\section{Direct TB antigen detection}

Lipoarabinomannan (LAM), a cell wall component of M. tuberculosis, is the target antigen detected in urine samples by the commercialised Determine LAM assay, a rapid, inexpensive and noninvasive lateral flow test that does not require a laboratory or technical equipment. The LAM assay has been demonstrated to have good accuracy mainly in people living with HIV with low CD4 T-cell counts [134]. Efforts are ongoing to evaluate LAM as a sputum marker for treatment monitoring. Although it is not yet commercially available, an ELISA for use in drug trials obtained promising results [135].

Another promising method to rapidly quantify $\mathrm{TB}$ antigens in the blood is the identification of M. tuberculosis-specific peptide fragments using energy-focusing porous discoidal silicon nanoparticles (nanodisks) coupled to mass spectrometry. This high-sensitivity quantification technique uses antibody-conjugated nanodisks to enrich two $M$. tuberculosis-specific peptides, of CFP-10 and ESAT-6, from trypsin-digested serum samples, which are then quantified by matrix-assisted laser desorption/ ionisation time-of-flight mass spectrometry using isotope-labelled internal standard peptides. LiU et al. [136] found that the serum levels of M. tuberculosis peptides associate to active TB and decrease after specific therapy. Therefore, the detection of the M. tuberculosis-specific antigens can be a marker to monitor TB therapy efficacy.

\section{Modulation of monocytic and lymphocytic cell populations}

In the 1920s it was shown in a rabbit model that a higher ratio between peripheral blood monocytes and lymphocytes, known as the monocyte/lymphocyte $(\mathrm{M} / \mathrm{L})$ ratio, was associated with progressive active $\mathrm{TB}$ $[137,138]$. This finding was confirmed in humans $[139,140]$ and, recently, it was shown that the M/L ratio returned to levels found in healthy donors upon TB cure [141]. This finding may be related to decreased inflammation during effective TB treatment, leading to decreased myelopoiesis in the bone marrow, which is known to be driven by IFN- $\gamma$ produced during the antimycobacterial response [139, 142]. Since lymphopoiesis is not activated in a similar manner and peripheral lymphoid cells are probably recruited to the site of $M$. tuberculosis replication during disease [105], TB treatment may lead to an increase in peripheral blood lymphoid cells. Therefore, the higher $\mathrm{M} / \mathrm{L}$ ratio observed in TB disease is probably a product of the polar effects of inflammation on myeloid and lymphoid cells, which are reversed to normal levels after effective treatment [141].

\section{Other immunological markers}

M. tuberculosis induces the expression of the indoleamine 2,3-dioxygenase (IDO), an enzyme that catabolises tryptophan, which affects host immunity, dramatically suppressed by tryptophan metabolites [143]. Interestingly, in a Japanese study, pulmonary TB patients had significant increases in IDO activity and significant decreases in tryptophan concentrations compared to control subjects [144]. Furthermore, increased IDO activity was associated with progression to TB in HIV-infected patients, while its decrease was significantly reported after efficacious therapy [145]. Recently, blockade of IDO activity in macaques was demonstrated to reduce both clinical $\mathrm{TB}$ manifestations as well as microbial and pathological characteristics, such as altered granuloma organisation, with more T-cells with proliferative signatures translocated to the lesion core [146]. These results indicate that the available safe and approved anti-IDO compounds could be tested for chemotherapy-adjunctive host-directed TB therapy.

Monocytic myeloid-derived suppressor cells (MDSCs) are bona fide phagocytes that internalise the pathogens, and then persist suppressing the local immune responses [147]. These cells are present in cancer and other pathological processes such as traumatic stress, sepsis, acute inflammation and bacterial, viral and parasitic infections [148]. MDSC are defined in humans as $\mathrm{CD} 11 \mathrm{~b}^{+} \mathrm{CD} 14^{-} \mathrm{CD} 33^{+} \mathrm{CD} 15^{+}$and HLA-DRlow (granulocytic MDSCs) or CD $11 \mathrm{~b}^{+} \mathrm{CD} 14^{+} \mathrm{CD} 33^{+}$and HLA-DRlow (monocytic MDSCs). They are characterised by their ability to suppress $\mathrm{T}$-cell responses through diverse mechanisms. It has been shown that MDSCs are increased in blood $[149,150]$ and in lungs of patients with pulmonary TB and decrease after successful therapy [150].

\section{Inflammation and acute phase response markers}

A range of activation markers can serve as biomarkers for TB disease and treatment response. IFN- $\gamma$ inducible protein (IP)-10 is a chemokine secreted by multiple cell types, including monocytes, endothelial cells and fibroblasts, in response to IFN- $\gamma$. IP-10 acts as a chemoattractant for monocytes/macrophages, T-cells, natural killer cells and dendritic cells and promotes T-cell adhesion [151, 152]. Concentrations of soluble IP-10 in patients with TB disease, either with or without HIV co-infection, are elevated in plasma or serum, measured either after M. tuberculosis antigen exposure or direct ex vivo in unstimulated blood [96, 153-155] or in urine [156-158]. High levels of plasma IP-10 were associated with active TB in both HIV-uninfected [155, 159] and -infected subjects [160] and decreased after therapy [153]. Similar findings were obtained in urine samples [158]. These results were reviewed recently [161]. 
Circulating levels of C-reactive protein (CRP), an established biomarker of systemic inflammation, has been described to reflect TB disease severity and radiographic improvement after 2 months of treatment $[162,163]$. In an African study, CRP decreased significantly after 2 months of treatment, whereas levels of $\beta_{2}$-microglobulin, a component of class I MHC found in a free state in various body fluids in different disease pathologies [164], and neopterin, a clinical marker of immune activation during inflammation [165] showed little change by 2 months, but a significant decrease after 6 months of treatment [166]. Interestingly, at recruitment, $\beta_{2}$-microglobulin levels were significantly higher in subjects infected with Mycobacterium africanum compared with those infected with M. tuberculosis sensu stricto [166]. In addition, while CRP and neopterin showed a highly significant decline post-treatment regardless of strain, $\beta_{2}$-microglobulin showed differential decline depending on $M$. tuberculosis strain, and levels were still significantly higher at 6 months in M. africanum-compared to M. tuberculosis-infected subjects. Interestingly, in accordance with $\beta_{2}$-microglobulin, at the end of treatment the decline in serum pro-inflammatory metabolites was more pronounced in M. tuberculosis-infected than in M. africanum-infected patients. Since M. tuberculosis-infected patients showed greater improvement than M. africanum-infected patients in all clinical parameters following a similar length of anti-TB therapy, these results might be indicative of host factors as potential markers for differential efficacy of the standard anti-TB treatment on the two lineages [167].

Results from the same laboratory supported this possibility; in fact, they showed that post-TB therapy in unstimulated blood cells of $M$. africanum-infected patients had a higher production of inflammation-associated cytokines and genes (interleukin (IL)-12p70, IL12A and Toll-like receptor (TLR) 9) while those of $M$. tuberculosis-infected individuals had higher level of disease resolution cytokines (IFN- $\gamma$, TNF- $\alpha$, CCL4, IL1 $\beta$ and TLR4) when stimulated with ESAT-6/CFP-10 [168].

Interestingly, a diagnostic biosignature of TB based on the relative levels of seven soluble serum markers, including inflammatory mediators such as IP-10, CRP, IFN- $\gamma$, serum amyloid A, complement factor $\mathrm{H}$, apolipoprotein-A1 and transthyretin, has been described [155]. This signature has high accuracy for TB, regardless of HIV infection status or African country of sample origin [155]. Efforts are now ongoing to incorporate this protein biomarker signature into a simple-to-use and field friendly lateral-flow test [169]. Of interest, these markers are mostly mediators of innate immunity and inflammation, therefore, independently confirming the biological processes underlying TB disease that have also emerged from transcriptomic (see later) and immune (and perhaps metabolomic) signatures.

A possible supportive strategy to shorten the treatment time is to estimate the inflammatory status of the patients. Since it has been reported that culture conversion occurs earlier than lung tissue repair [17], it would be very helpful to evaluate serum markers of tissue repair [170,171] as relapse-free indicators of treatment outcome, without assessing pulmonary pathology by chest radiography or PET/CT. Good candidates are markers of platelet activity, since they are increased in plasma of patients with pulmonary $\mathrm{TB}$, when compared to healthy controls, and then normalise after antimycobacterial treatment [4]. Additional candidates are the evaluation of the proportions of M. tuberculosis-specific CD27low CD4 ${ }^{+}$ T-cells, which decline in parallel to the reduction of lung tissue damage [65]. Other potential serum markers are vascular endothelial growth factor, matrix metalloproteinase-9, transforming growth factor (TGF)- $\beta 1$ and aminoterminal propeptide of type III procollagen (PIIINP) [172-176].

\section{Blood transcriptomic signatures}

Elevated expression by whole-blood leukocytes of mRNA transcripts of type I/II IFN genes or IFN-stimulated genes (ISGs) have been associated with active TB. Moreover, several transcriptomic signatures have been developed mainly in M. tuberculosis-monoinfected patients [93, 177-181], but also in cohorts containing both HIV-co-infected and HIV-uninfected individuals [182]. These signatures reflect disease-associated inflammation, which decreases during TB treatment, and have also been suggested as biomarkers for treatment monitoring [177, 183-186]. Blood gene expression signatures are used to characterise disease severity and monitor treatment for several other diseases, including cancer and autoimmune diseases [187-189]. Transcriptional profiling of whole blood from individuals with active TB, LTBI and cured TB revealed upregulated ISGs (both type I and type II), myeloid and inflammatory genes and downregulated transcripts of B- and T-cell genes during active disease [177]. In addition, the extent of disease evaluated using chest radiography correlated with the magnitude of the type I/II IFN transcriptional signature, suggesting that inflammatory profiles in the blood mirror to some extent the disease processes in the lung. A recent study showed that detection of changes in type I/II IFN and complement pathways, myeloid inflammation and monocytes, neutrophils, B-cell and T-cell genes can be used to map how individuals transition through the different phases of progression from M. tuberculosis infection to TB disease [105]. It has been reported that soon after the initiation of anti-TB therapy, an initial fast downregulation of inflammatory mediators coincided with rapid killing of actively dividing 
bacilli, whereas slower changes in other inflammatory mediators coincided with lung pathology resolution $[184,186]$. These findings suggest that monitoring of blood gene expression during TB treatment provide insight into clearance of $M$. tuberculosis and resolution of disease-associated inflammation. A 16-gene type I/II IFN transcriptional signature, previously discovered and validated as a correlate of risk of TB [190], could identify patients at risk of TB treatment failure as early as 1-4 weeks after start of treatment [185]. Additionally, this study discovered a novel, parsimonious five-gene transcriptional signature (RESPONSE5) that allowed treatment response monitoring and prediction of treatment failure with high accuracy, further supporting the case for blood-based biomarkers for TB [185]. Interestingly, the RESPONSE5 signature correlated with total pulmonary inflammation measured by PET/CT [185]. These data suggest that a whole-blood signature can capture aspects of the host immune response reflecting the extent of TB disease and/or in determining treatment outcome, mainly in terms of resolution of inflammation.

\section{Radiology}

In patients with active $\mathrm{TB}$, imaging is often requested to evaluate the degree of disease, while it is used during and after TB treatment to assess response to therapy or detect residual infection, respectively. Despite the advent of CT, PET/CT and magnetic resonance imaging, conventional radiography remains the initial modality for TB screening purposes [191].

As mentioned above, the measure of pulmonary inflammation through cellular uptake of ${ }^{18}$ F-labelled FDG by PET/CT scanning is considered as a possible surrogate of ongoing $M$. tuberculosis replication [17]. Moreover, it has been reported almost 30\% of HIV-1-infected LTBI subjects had pulmonary abnormalities compatible with subclinical active infection, which was confirmed by the finding that four out of 10 progressed to microbiologically proven TB disease within 6 months [22]. Although PET/CT scanning does not qualify as a routine diagnostic test platform, the emerging new insights from this work further support the concept that inflammation is a marker of treatment efficacy and subsequent risk of TB relapse.

\section{Conclusions and implications}

Currently, there is the need for better tests to guide treatment decisions in TB. Considering ideal product profiles, two types of test, one for treatment monitoring and one for cure, would probably be preferred to replace old, time-consuming and insensitive techniques. A test of cure would be able to accurately predict treatment success at an early stage of treatment and inform timing of treatment termination. A treatment monitoring test can be used to measure response to TB therapy to identify at an early stage those patients who will fail treatment and may benefit from host-directed therapies, or who would benefit from longer treatment regimens. Ideally, both tests should be easy to perform by nonlaboratory staff in order to be implemented at peripheral treatment facilities with no attached laboratory. Simple, low cost, instrument free and easy to interpret tests will be most likely to be adopted in high-burden countries. That said, a centralised, more complex test could be considered as well, if it were affordable and the sample transport and results reporting system were place. Simple tests, such as those based on a single antigen, e.g. LAM in sputum, show a lot of promise and may soon be translated into a commercial assay, although further validation studies are needed. Other single-marker approaches rely on nonspecific targets such as IP-10 or CRP, which would probably be affected by the status of the patient's immune system. In addition, efforts have been made to develop highly parsimonious molecular signatures as diagnostic and/or prognostic for TB. Recently, SwEEney et al. [192] reviewed public datasets and generated a biosignature of only three genes associated to active TB diagnosis, which expression declined upon specific therapy. Although other molecular signatures have been recently developed for the diagnosis or progression to active TB such as a four-gene signature [193] or 47 circulating microRNA [194], validation is necessary to investigate whether they can be used as prognostic markers for TB treatment.

Quite complex detection systems will be necessary for T-cell activation markers, expression signatures, or markers reliant on a stimulation and or incubation. These more complex assays may perform well and it will be important to translate these into formats that can be used in limited resource settings.

The current data can be summarised to say that no novel test for cure or treatment monitoring is likely to be immediately forthcoming. While a lot of work on different biomarkers is further enriching our understanding of the pathogenesis of TB and particularly the continuum between latent $M$. tuberculosis infection and active $\mathrm{TB}$, a single biomarker that is indicative for treatment response remains elusive. Moreover, once biomarkers for TB cure are identified, long follow-up studies to evaluate their capacity to predict a relapse will be required. The work utilising PET/CT [17] is helping us to understand that even the entity of "cure" might not be uniform.

Acknowledgements: We thank Linda Petrone and Elisa Petruccioli (National Institute for Infectious Diseases "L. Spallanzani" IRCCS Rome, Italy), for help with figure editing. We sincerely apologise to all those colleagues whose important work was not cited due to space constraints. 
Conflict of interest: D. Goletti reports personal fees from Qiagen, Quidel and Janssen, outside the submitted work. C.S. Lindestam Arlehamn has nothing to disclose. T.J. Scriba reports two pending patents of blood transcriptomic signatures of risk. R. Anthony reports grants from FIND to study the utility of IP-10 for treatment monitoring, outside the submitted work. D.M. Cirillo reports an unrestricted grant from QIAGEN to research the use of Quantiferon plus to predict outcome, and grants from JANSSEN on the establishment of Bedaquiline DST as SRL, outside the submitted work. T. Alonzi has nothing to disclose. C.M. Denkinger reports that FIND is a non-for-profit foundation, whose mission is to find diagnostic solutions to overcome diseases of poverty in LMICs. It works closely with the private and public sectors and receives funding from some of its industry partners. It has organisational firewalls to protect it against any undue influences in its work or the publication of its findings. All industry partnerships are subject to review by an independent scientific advisory committee or another independent review body, based on due diligence, TTPs and public sector requirements. FIND catalyses product development, leads evaluations, takes positions, and accelerates access to tools identified as serving its mission. It provides indirect support to industry (e.g. access to open specimen banks, a clinical trial platform, technical support, expertise, laboratory capacity strengthening in LMICs) to facilitate the development and use of products in these areas. FIND also supports the evaluation of prioritised assays and the early stages of implementation of WHO-approved (guidance and PQ) assays using donor grants. In order to carry out test validations and evaluations, has product evaluation agreements with several private sector companies for the diseases FIND works in which strictly define its independence and neutrality vis-a-vis the companies whose products get evaluated, and describes roles and responsibilities. F. Cobelens has nothing to disclose.

Support statement: The study was supported by grants from the European Union (643381-TBVAC2020-H2020-PHC-2014-2015), a grant from the National Institutes of Health of USA (NIH 1R21AI127133-01), funding from Italian Ministry of Health "Ricerca Finalizzata": RF-2011-02349395 and from the Italian Ministry of Health ("Ricerca Corrente"). Funding information for this article has been deposited with the Crossref Funder Registry.

\section{References}

1 World Health Organization. Global Tuberculosis Report 2017. www.who.int/tb/publications/global_report/en/

2 Falzon D, Schünemann HJ, Harausz E, et al. World Health Organization treatment guidelines for drug-resistant tuberculosis, 2016 update. Eur Respir J 2017; 49: 1602308.

3 Mitchison D, Davies G. The chemotherapy of tuberculosis: past, present and future. Int J Tuberc Lung Dis 2012 16: 724-732.

4 Fox KA, Kirwan DE, Whittington AM, et al. Platelets regulate pulmonary inflammation and tissue destruction in tuberculosis. Am J Respir Crit Care Med 2018; 198: 245-255.

5 Lienhardt C, Raviglione M, Spigelman M, et al. New drugs for the treatment of tuberculosis: needs, challenges, promise, and prospects for the future. J Infect Dis 2012; 205: Suppl. 2, S241-S249.

6 Lienhardt $\mathrm{C}$, Lönnroth $\mathrm{K}$, Menzies $\mathrm{D}$, et al. Translational research for tuberculosis elimination: priorities, challenges, and actions. PLoS Med 2016; 13: e1001965.

7 Goletti D, Petruccioli E, Joosten SA, et al. Tuberculosis biomarkers: from diagnosis to protection. Infect Dis Rep 2016; 8: 6568

8 Goletti D, Lee MR, Wang JY, et al. Update on tuberculosis biomarkers: from correlates of risk, to correlates of active disease and of cure from disease. Respirology 2018; 23: 455-466.

9 World Health Organization (WHO). Treatment of Tuberculosis: Guidelines for National Programmes, 3rd edn 2003. whqlibdoc.who.int/hq/2003/WHO_CDS_TB_2003.313_eng.pdf

10 Watterson SA, Drobniewski FA. Modern laboratory diagnosis of mycobacterial infections. J Clin Pathol 2000; 53: 727-732.

11 Katz J, Kunofsky S, Locke B. Reactivation of inactive pulmonary tuberculosis. Am Rev Tuberc 1956; 73: 31-39.

12 Lambert ML, Hasker E, Van Deun A, et al. Recurrence in tuberculosis: relapse or reinfection? Lancet Infect Dis 2003; 3: 282-287.

13 Guerra-Assunção JA, Houben RM, Crampin AC, et al. Recurrence due to relapse or reinfection with Mycobacterium tuberculosis: a whole-genome sequencing approach in a large, population-based cohort with a high HIV infection prevalence and active follow-up. J Infect Dis 2015; 211: 1154-1163.

14 Getahun H, Matteelli A, Abubakar I, et al. Management of latent Mycobacterium tuberculosis infection: WHO guidelines for low tuberculosis burden countries. Eur Respir J 2015; 46: 1563-1576.

15 Houben RMGJ, Menzies NA, Sumner T, et al. Feasibility of achieving the 2025 WHO global tuberculosis targets in South Africa, China, and India: a combined analysis of 11 mathematical models. Lancet Glob Health 2016; 4: e806-e815.

16 Ankrah AO, Glaudemans AWJM, Maes A, et al. Tuberculosis. Semin Nucl Med 2018; 48: 108-130.

17 Malherbe ST, Shenai S, Ronacher K, et al. Persisting positron emission tomography lesion activity and Mycobacterium tuberculosis mRNA after tuberculosis cure. Nat Med 2016; 22: 1094-1100.

18 Ordonez AA, Pokkali S, DeMarco VP, et al. Radioiodinated DPA-713 imaging correlates with bactericidal activity of tuberculosis treatments in mice. Antimicrob Agents Chemother 2015; 59: 642-649.

19 White AG, Maiello P, Coleman MT, et al. Analysis of ${ }^{18} \mathrm{FDG}$ PET/CT imaging as a tool for studying Mycobacterium tuberculosis infection and treatment in non-human primates. J Vis Exp 2017; doi: 10.3791/56375.

20 Onozaki I, Law I, Sismanidis C, et al. National tuberculosis prevalence surveys in Asia, 1990-2012: an overview of results and lessons learned. Trop Med Int Health 2015; 20: 1128-1145.

21 Wood R, Middelkoop K, Myer L, et al. Undiagnosed tuberculosis in a community with high HIV prevalence: implications for tuberculosis control. Am J Respir Crit Care Med 2007; 175: 87-93.

22 Esmail H, Lai RP, Lesosky $\mathrm{M}$, et al. Characterization of progressive HIV-associated tuberculosis using 2-deoxy-2- $\left[{ }^{18}\right.$ F] fluoro-D-glucose positron emission and computed tomography. Nat Med 2016; 22: 1090-1093.

23 Lin PL, Rodgers M, Smith L, et al. Quantitative comparison of active and latent tuberculosis in the cynomolgus macaque model. Infect Immun 2009; 77: 4631-4642. 

macaques against active tuberculosis and reactivation of latent Mycobacterium tuberculosis infection. J Clin Invest 2012; 122: 303-314.

25 Obregon-Henao A, Shanley CA, Shang S, et al. Cortisone-forced reactivation of weakly acid fast positive Mycobacterium tuberculosis in guinea pigs previously treated with chemotherapy. Mycobac Dis 2012; 2: 116-122.

26 Nunn AJ, Phillips PP, Mitchison DA. Timing of relapse in short-course chemotherapy trials for tuberculosis. Int J Tuberc Lung Dis 2010; 14: 241-242.

27 Marx FM, Dunbar R, Enarson DA, et al. The temporal dynamics of relapse and reinfection tuberculosis after successful treatment: a retrospective cohort study. Clin Infect Dis 2014; 58: 1676-1683.

28 Shen X, Yang C, Wu J, et al. Recurrent tuberculosis in an urban area in China: relapse or exogenous reinfection? Tuberculosis 2017; 103: 97-104.

29 Gilpin C, Kim SJ, Lumb R, et al. Critical appraisal of current recommendations and practices for tuberculosis sputum smear microscopy. Int J Tuberc Lung Dis 2007; 11: 946-952.

30 Steingart KR, Ramsay A, Pai M. Optimizing sputum smear microscopy for the diagnosis of pulmonary tuberculosis. Expert Rev Anti Infect Ther 2007; 5: 327-331.

31 Aung KJ, Van Deun A, Declercq E, et al. Successful '9-month Bangladesh regimen' for multidrug-resistant tuberculosis among over 500 consecutive patients. Int J Tuberc Lung Dis 2014; 18: 1180-1187.

32 Horne DJ, Royce SE, Gooze L, et al. Sputum monitoring during tuberculosis treatment for predicting outcome: systematic review and meta-analysis. Lancet Infect Dis 2010; 10: 387-394.

33 Hamid Salim A, Aung KJ, Hossain MA, et al. Early and rapid microscopy-based diagnosis of true treatment failure and MDR-TB. Int J Tuberc Lung Dis 2006; 10: 1248-1254.

34 Datta S, Sherman JM, Bravard MA, et al. Clinical evaluation of tuberculosis viability microscopy for assessing treatment response. Clin Infect Dis 2015; 60: 1186-1195.

35 Datta S, Sherman JM, Tovar MA, et al. Sputum microscopy with fluorescein diacetate predicts tuberculosis infectiousness. J Infect Dis 2017; 216: 514-524.

36 Wallis RS, Peppard T, Hermann D. Month 2 culture status and treatment duration as predictors of recurrence in pulmonary tuberculosis: model validation and update. PLoS One 2015; 10: e0125403.

37 Benator D, Bhattacharya M, Bozeman L, et al. Rifapentine and isoniazid once a week versus rifampicin and isoniazid twice a week for treatment of drug-susceptible pulmonary tuberculosis in HIV-negative patients: a randomised clinical trial. Lancet 2002; 360: 528-534.

38 Phillips PP, Fielding K, Nunn AJ. An evaluation of culture results during treatment for tuberculosis as surrogate endpoints for treatment failure and relapse. PLoS One 2013; 8: e63840.

39 Kurbatova EV, Cegielski JP, Lienhardt C, et al. Sputum culture conversion as a prognostic marker for end-of-treatment outcome in patients with multidrug-resistant tuberculosis: a secondary analysis of data from two observational cohort studies. Lancet Respir Med 2015; 3: 201-209.

40 Lu P, Liu Q, Martinez L, et al. Time to sputum culture conversion and treatment outcome of patients with multidrug-resistant tuberculosis: a prospective cohort study from urban China. Eur Respir J 2017; 49: 1601558.

41 Krüüner A, Yates MD, Drobniewski FA. Evaluation of MGIT 960-based antimicrobial testing and determination of critical concentrations of first- and second-line antimicrobial drugs with drug-resistant clinical strains of Mycobacterium tuberculosis. J Clin Microbiol 2006; 44: 811-818.

42 Johnson JL, Hadad DJ, Dietze R, et al. Shortening treatment in adults with noncavitary tuberculosis and 2-month culture conversion. Am J Respir Crit Care Med 2009; 180: 558-563.

43 Donald PR, Diacon AH. The early bactericidal activity of anti-tuberculosis drugs: a literature review. Tuberculosis 2008; 88: Suppl. 1, S75-S83.

44 van den Boogaard J, Kibiki GS, Kisanga ER, et al. New drugs against tuberculosis: problems, progress, and evaluation of agents in clinical development. Antimicrob Agents Chemother 2009; 53: 849-862.

45 Koul A, Arnoult E, Lounis N, et al. The challenge of new drug discovery for tuberculosis. Nature 2011; 469: 483-490.

46 Brindle R, Odhiambo J, Mitchison D. Serial counts of Mycobacterium tuberculosis in sputum as surrogate markers of the sterilising activity of rifampicin and pyrazinamide in treating pulmonary tuberculosis. BMC Pulm Med 2001; 1: 2 .

47 Jindani A, Aber VR, Edwards EA, et al. The early bactericidal activity of drugs in patients with pulmonary tuberculosis. Am Rev Respir Dis 1980; 121: 939-949.

48 Goutelle S, Bourguignon L, Jelliffe RW, et al. Mathematical modeling of pulmonary tuberculosis therapy: insights from a prototype model with rifampin. J Theor Biol 2011; 282: 80-92.

49 Friedrich SO, Rachow A, Saathoff E, et al. Assessment of the sensitivity and specificity of Xpert MTB/RIF assay as an early sputum biomarker of response to tuberculosis treatment. Lancet Respir Med 2013; 1: 462-470.

50 Miotto P, Bigoni S, Migliori GB, et al. Early tuberculosis treatment monitoring by Xpert ${ }^{\star}$ MTB/RIF. Eur Respir J 2012; 39: 1269-1271.

51 Nikolayevskyy V, Miotto P, Pimkina E, et al. Utility of propidium monoazide viability assay as a biomarker for a tuberculosis disease. Tuberculosis 2015; 95: 179-185.

52 Li L, Mahan CS, Palaci M, et al. Sputum Mycobacterium tuberculosis mRNA as a marker of bacteriologic clearance in response to antituberculosis therapy. J Clin Microbiol 2010; 48: 46-51.

53 Honeyborne I, McHugh TD, Phillips PP, et al. Molecular bacterial load assay, a culture-free biomarker for rapid and accurate quantification of sputum Mycobacterium tuberculosis bacillary load during treatment. J Clin Microbiol 2011; 49: 3905-3911.

54 Honeyborne I, Mtafya B, Phillips PP, et al. The molecular bacterial load assay replaces solid culture for measuring early bactericidal response to antituberculosis treatment. J Clin Microbiol 2014; 52: 3064-3067.

55 Shenai S, Ronacher K, Malherbe S, et al. Bacterial loads measured by the Xpert MTB/RIF assay as markers of culture conversion and bacteriological cure in pulmonary TB. PLoS One 2016; 11: e0160062.

56 Jayakumar A, Savic RM, Everett CK, et al. Xpert MTB/RIF assay shows faster clearance of Mycobacterium tuberculosis DNA with higher levels of rifapentine exposure. J Clin Microbiol 2016; 54: 3028-3033.

57 Dorman SE, Schumacher SG, Alland D, et al. Xpert MTB/RIF Ultra for detection of Mycobacterium tuberculosis and rifampicin resistance: a prospective multicentre diagnostic accuracy study. Lancet Infect Dis 2018; 18: 76-84. 
Watts TH. TNF/TNFR family members in costimulation of T cell responses. Annu Rev Immunol 2005; 23: 23-68.

Fritsch RD, Shen X, Sims GP, et al. Stepwise differentiation of CD4 memory T cells defined by expression of CCR7 and CD27. J Immunol 2005; 175: 6489-6497.

Lyadova IV, Oberdorf S, Kapina MA, et al. CD4 T cells producing IFN- $\gamma$ in the lungs of mice challenged with mycobacteria express a CD27-negative phenotype. Clin Exp Immunol 2004; 138: 21-29.

Lyadova IV, Panteleev AV. Th1 and Th17 cells in tuberculosis: protection, pathology, and biomarkers. Mediators Inflamm 2015; 2015: 854507.

Petruccioli E, Petrone L, Vanini V, et al. Assessment of CD27 expression as a tool for active and latent tuberculosis diagnosis. J Infect 2015; 71: 526-533.

Portevin D, Moukambi F, Clowes P, et al. Assessment of the novel T-cell activation marker-tuberculosis assay for diagnosis of active tuberculosis in children: a prospective proof-of-concept study. Lancet Infect Dis 2014; 14: 931-938.

Prezzemolo T, Guggino G, La Manna MP, et al. Functional signatures of human CD4 and CD8T cell responses to Mycobacterium tuberculosis. Front Immunol 2014; 5: 180.

Nikitina IY, Kondratuk NA, Kosmiadi GA, et al. Mtb-specific CD27low CD4 T cells as markers of lung tissue destruction during pulmonary tuberculosis in humans. PLoS One 2012; 7: e43733.

Musvosvi M, Duffy D, Filander E, et al. T-cell biomarkers for diagnosis of tuberculosis: candidate evaluation by a simple whole blood assay for clinical translation. Eur Respir J 2018; 51: 1800153.

Nikitina IY, Panteleev AV, Sosunova EV, et al. Antigen-specific IFN- $\gamma$ responses correlate with the activity of $M$. tuberculosis infection but are not associated with the severity of tuberculosis disease. J Immunol Res 2016; 2016: 7249369.

Panteleev AV, Nikitina IY, Burmistrova IA, et al. Severe tuberculosis in humans correlates best with neutrophil abundance and lymphocyte deficiency and does not correlate with antigen-specific CD4 T-cell response. Front Immunol 2017; 8: 963.

Schuetz A, Haule A, Reither K, et al. Monitoring CD27 expression to evaluate Mycobacterium tuberculosis activity in HIV-1 infected individuals in vivo. PLoS One 2011; 6: e27284.

Petruccioli E, Navarra A, Petrone L, et al. Use of several immunological markers to model the probability of active tuberculosis. Diagn Microbiol Infect Dis 2016; 86: 169-171.

Orciani M, Trubiani O, Guarnieri S, et al. CD38 is constitutively expressed in the nucleus of human hematopoietic cells. J Cell Biochem 2008; 105: 905-912.

Shubinsky G, Schlesinger M. The CD38 lymphocyte differentiation marker: new insight into its ectoenzymatic activity and its role as a signal transducer. Immunity 1997; 7: 315-324.

Marsh SG. Nomenclature for factors of the HLA system, update September 2005. Int J Immunogenet 2005; 32: 431-432.

Scholzen T, Gerdes J. The Ki-67 protein: from the known and the unknown. J Cell Physiol 2000; 182: 311-322. treatment response. J Clin Invest 2015; 125: 1827-1838.

Wilkinson KA, Oni T, Gideon HP, et al. Activation profile of Mycobacterium tuberculosis-specific CD4 ${ }^{+} \mathrm{T}$ cells reflects disease activity irrespective of HIV status. Am J Respir Crit Care Med 2016; 193: 1307-1310.

Goletti D, Butera O, Bizzoni F, et al. Region of difference 1 antigen-specific $\mathrm{CD} 4^{+}$memory T cells correlate with a favorable outcome of tuberculosis. J Infect Dis 2006; 194: 984-992.

Petruccioli E, Vanini V, Chiacchio T, et al. Analytical evaluation of QuantiFERON-Plus and QuantiFERON-Gold In-tube assays in subjects with or without tuberculosis. Tuberculosis 2017; 106: 38-43.

Denkinger CM, Pai M, Patel M, et al. Gamma interferon release assay for monitoring of treatment response for active tuberculosis: an explosion in the spaghetti factory. J Clin Microbiol 2013; 51: 607-610.

Carrara S, Vincenti D, Petrosillo N, et al. Use of a T cell-based assay for monitoring efficacy of antituberculosis therapy. Clin Infect Dis 2004; 38: 754-756.

Aiken AM, Hill PC, Fox A, et al. Reversion of the ELISPOT test after treatment in Gambian tuberculosis cases. BMC Infect Dis 2006; 6: 66.

Pathan AA, Wilkinson KA, Klenerman P, et al. Direct ex vivo analysis of antigen-specific IFN- $\gamma$-secreting CD4 T cells in Mycobacterium tuberculosis-infected individuals: associations with clinical disease state and effect of treatment. J Immunol 2001; 167: 5217-5225.

Kobashi Y, Mouri K, Yagi S, et al. Transitional changes in T-cell responses to Mycobacterium tuberculosis-specific antigens during treatment. J Infect 2009; 58: 197-204.

Kobashi Y, Sugiu T, Ohue Y, et al. Long-term follow-up of the QuantiFERON TB-2G test for active tuberculosis disease. Intern Med 2008; 47: 1957-1961.

Park IN, Shim TS. Qualitative and quantitative results of interferon- $\gamma$ release assays for monitoring the response to anti-tuberculosis treatment. Korean J Intern Med 2017; 32: 302-308.

Wang F, Hou HY, Wu SJ, et al. Using the TBAg/PHA ratio in the T-SPOT ${ }^{\oplus}$.TB assay to distinguish TB disease from LTBI in an endemic area. Int J Tuberc Lung Dis 2016; 20: 487-493.

Wang $\mathrm{F}, \mathrm{Yu}$ J, Zhou $\mathrm{Y}$, et al. The use of TB-specific antigen/phytohemagglutinin ratio for diagnosis and treatment monitoring of extrapulmonary tuberculosis. Front Immunol 2018; 9: 1047.

Day CL, Abrahams DA, Lerumo L, et al. Functional capacity of Mycobacterium tuberculosis-specific T cell responses in humans is associated with mycobacterial load. J Immunol 2011; 187: 2222-2232.

Petruccioli E, Petrone L, Vanini V, et al. IFN $\gamma / \mathrm{TNF} \alpha$ specific-cells and effector memory phenotype associate with active tuberculosis. J Infect 2013; 66: 475-486.

Chiacchio T, Petruccioli E, Vanini V, et al. Polyfunctional T-cells and effector memory phenotype are associated with active TB in HIV-infected patients. J Infect 2014; 69: 533-545.

Day CL, Abrahams DA, Harris LD, et al. HIV-1 infection is associated with depletion and functional impairment of Mycobacterium tuberculosis-specific CD4 T cells in individuals with latent tuberculosis infection. J Immunol 2017; 199: 2069-2080.

Moguche AO, Musvosvi M, Penn-Nicholson A, et al. Antigen availability shapes $\mathrm{T}$ cell differentiation and function during tuberculosis. Cell Host Microbe 2017; 21: 695-706. 
93 Andersen P, Doherty TM, Pai M, et al. The prognosis of latent tuberculosis: can disease be predicted? Trends Mol Med 2007; 13: 175-182.

94 Shi L, North R, Gennaro ML. Effect of growth state on transcription levels of genes encoding major secreted antigens of Mycobacterium tuberculosis in the mouse lung. Infect Immun 2004; 72: 2420-2424.

95 Rogerson BJ, Jung YJ, LaCourse R, et al. Expression levels of Mycobacterium tuberculosis antigen-encoding genes versus production levels of antigen-specific $\mathrm{T}$ cells during stationary level lung infection in mice. Immunology 2006; 118: 195-201.

96 Goletti D, Raja A, Ahamed Kabeer BS, et al. IFN- $\gamma$, but not IP-10, MCP-2 or IL-2 response to RD1 selected peptides associates to active tuberculosis. J Infect 2010; 61: 133-143.

97 Vincenti D, Carrara S, Butera O, et al. Response to region of difference 1 (RD1) epitopes in human immunodeficiency virus (HIV)-infected individuals enrolled with suspected active tuberculosis: a pilot study. Clin Exp Immunol 2007; 150: 91-98.

98 Kabeer BS, Raja A, Raman B, et al. IP-10 response to RD1 antigens might be a useful biomarker for monitoring tuberculosis therapy. BMC Infect Dis 2011; 11: 135.

99 Goletti D, Carrara S, Mayanja-Kizza H, et al. Response to M. tuberculosis selected RD1 peptides in Ugandan HIV-infected patients with smear positive pulmonary tuberculosis: a pilot study. BMC Infect Dis 2008; 8: 11.

100 Menozzi FD, Rouse JH, Alavi M, et al. Identification of a heparin-binding hemagglutinin present in mycobacteria. J Exp Med 1996; 184: 993-1001.

101 Delogu G, Chiacchio T, Vanini V, et al. Methylated HBHA produced in M. smegmatis discriminates between active and non-active tuberculosis disease among RD1-responders. PLoS One 2011; 6: e18315.

102 Hougardy JM, Schepers K, Place S, et al. Heparin-binding-hemagglutinin-induced IFN- $\gamma$ release as a diagnostic tool for latent tuberculosis. PLoS One 2007; 2: e926.

103 Hutchinson P, Barkham TM, Tang W, et al. Measurement of phenotype and absolute number of circulating heparin-binding hemagglutinin, ESAT-6 and CFP-10, and purified protein derivative antigen-specific CD4 T cells can discriminate active from latent tuberculosis infection. Clin Vaccine Immunol 2015; 22: $200-212$.

104 Chiacchio T, Delogu G, Vanini V, et al. Immune characterization of the HBHA-specific response in Mycobacterium tuberculosis-infected patients with or without HIV infection. PLoS One 2017; 12: e0183846.

105 Scriba TJ, Carpenter C, Pro SC, et al. Differential recognition of Mycobacterium tuberculosis-specific epitopes as a function of tuberculosis disease history. Am J Respir Crit Care Med 2017; 196: 772-781.

106 Barry CE 3rd, Boshoff HI, Dartois V, et al. The spectrum of latent tuberculosis: rethinking the biology and intervention strategies. Nat Rev Microbiol 2009; 7: 845-855.

107 Petruccioli E, Scriba TJ, Petrone L, et al. Correlates of tuberculosis risk: predictive biomarkers for progression to active tuberculosis. Eur Respir J 2016; 48: 1751-1763.

108 Corbière V, Pottier G, Bonkain F, et al. Risk stratification of latent tuberculosis defined by combined interferon gamma release assays. PLoS One 2012; 7: e43285.

109 Wolinsky E. Nontuberculous mycobacteria and associated diseases. Am Rev Respir Dis 1979; 119: $107-159$.

110 Glassroth J. Pulmonary disease due to nontuberculous mycobacteria. Chest 2008; 133: 243-251.

111 Hoefsloot W, van Ingen J, Andrejak C, et al. The geographic diversity of nontuberculous mycobacteria isolated from pulmonary samples: an NTM-NET collaborative study. Eur Respir J 2013; 42: 1604-1613.

112 Griffith DE, Aksamit T, Brown-Elliott BA, et al. An official ATS/IDSA statement: diagnosis, treatment, and prevention of nontuberculous mycobacterial diseases. Am J Respir Crit Care Med 2007; 175: 367-416.

113 Prevots DR, Marras TK. Epidemiology of human pulmonary infection with nontuberculous mycobacteria: a review. Clin Chest Med 2015; 36: 13-34.

114 Alvarez-Uria G. Lung disease caused by nontuberculous mycobacteria. Curr Opin Pulm Med 2010; 16: 251-256.

115 Falkinham JO 3rd. Surrounded by mycobacteria: nontuberculous mycobacteria in the human environment. J Appl Microbiol 2009; 107: 356-367.

116 Somoskovi A, Salfinger M. Nontuberculous mycobacteria in respiratory infections: advances in diagnosis and identification. Clin Lab Med 2014; 34: 271-295.

117 Comas I, Chakravartti J, Small PM, et al. Human T cell epitopes of Mycobacterium tuberculosis are evolutionarily hyperconserved. Nat Genet 2010; 42: 498-503.

118 Lindestam Arlehamn CS, Paul S, Mele F, et al. Immunological consequences of intragenus conservation of Mycobacterium tuberculosis T-cell epitopes. Proc Natl Acad Sci USA 2015; 112: E147-E155.

119 Collins FM. Immunogenicity of various mycobacteria and the corresponding levels of cross-protection developed between species. Infect Immun 1971; 4: 688-696.

120 Orme IM, Ratcliffe MJ, Collins FM. Acquired immunity to heavy infection with Mycobacterium bovis bacillus Calmette-Guérin and its relationship to the development of nonspecific unresponsiveness in vitro. Cell Immunol 1984; 88: 285-296.

121 Wilson ME, Fineberg HV, Colditz GA. Geographic latitude and the efficacy of bacillus Calmette-Guérin vaccine. Clin Infect Dis 1995; 20: 982-991.

122 Lindestam Arlehamn CS, McKinney DM, Carpenter C, et al. A quantitative analysis of complexity of human pathogen-specific CD4 T cell responses in healthy M. tuberculosis infected South Africans. PLoS Pathog 2016; 12: e1005760.

123 Carrasco Pro S, Sidney J, Paul S, et al. Automatic generation of validated specific epitope sets. J Immunol Res 2015; 2015: 763461.

124 Namasivayam S, Maiga M, Yuan W, et al. Longitudinal profiling reveals a persistent intestinal dysbiosis triggered by conventional anti-tuberculosis therapy. Microbiome 2017; 5: 71.

125 Wipperman MF, Fitzgerald DW, Juste MAJ, et al. Antibiotic treatment for tuberculosis induces a profound dysbiosis of the microbiome that persists long after therapy is completed. Sci Rep 2017; 7: 10767.

126 Rozot V, Patrizia A, Vigano S, et al. Combined use of Mycobacterium tuberculosis-specific CD4 and CD8 T-cell responses is a powerful diagnostic tool of active tuberculosis. Clin Infect Dis 2015; 60: 432-437.

127 Rozot V, Vigano S, Mazza-Stalder J, et al. Mycobacterium tuberculosis-specific CD8 ${ }^{+} \mathrm{T}$ cells are functionally and phenotypically different between latent infection and active disease. Eur J Immunol 2013; 43: 1568-1577.

128 Nikolova M, Markova R, Drenska R, et al. Antigen-specific CD4- and CD8-positive signatures in different phases of Mycobacterium tuberculosis infection. Diagn Microbiol Infect Dis 2013; 75: 277-281. 
Cliff JM, Cho JE, Lee JS, et al. Excessive cytolytic responses predict tuberculosis relapse after apparently successful treatment. J Infect Dis 2016; 213: 485-495.

Barcellini L, Borroni E, Brown J, et al. First evaluation of QuantiFERON-TB Gold Plus performance in contact screening. Eur Respir J 2016; 48: 1411-1419.

Barcellini L, Borroni E, Brown J, et al. First independent evaluation of QuantiFERON-TB Plus performance. Eur Respir J 2016; 47: 1587-1590.

Petruccioli E, Chiacchio T, Pepponi I, et al. First characterization of the CD4 and CD8 T-cell responses to QuantiFERON-TB Plus. J Infect 2016; 73: 588-597.

Kamada A, Amishima M. QuantiFERON-TB ${ }^{\circ}$ Gold Plus as a potential tuberculosis treatment monitoring tool. Eur Respir J 2017; 49: 1601976.

2018; 64: 1133-1135.

Liu Y. LAM (Lipoarabinomannan) as a Pharmacodynamic Biomarker and Drug Development Tool for TB. 2017. www.resisttb.org/wp-content/uploads/2017/06/Otsuka-LAM-test_Resist-TB-Webinar_06-22-2017.pdf

Liu C, Zhao Z, Fan J, et al. Quantification of circulating Mycobacterium tuberculosis antigen peptides allows rapid diagnosis of active disease and treatment monitoring. Proc Natl Acad Sci USA 2017; 114: 3969-3974.

Doan CA, Sabin FR. The relation of the tubercle and the monocyte:lymphocte ratio to resistance and susceptibility in tuberculosis. J Exp Med 1930; 52: 113-152.

Sabin FR, Doan CA, Cunningham RS. Studies of the blood in experimental tuberculosis: themonocytelymphocyte ratio; the anemia-leucopenia phase. Transactions of the 22nd Annual Meeting of the National Tuberculosis Association 1926; 22: 252-256.

Naranbhai V, Fletcher HA, Tanner R, et al. Distinct transcriptional and anti-mycobacterial profiles of peripheral blood monocytes dependent on the ratio of monocytes: lymphocytes. EBioMed 2015; 2: 1619-1626.

Rakotosamimanana N, Richard V, Raharimanga V, et al. Biomarkers for risk of developing active tuberculosis in contacts of TB patients: a prospective cohort study. Eur Respir J 2015; 46: 1095-1103.

La Manna MP, Orlando V, Dieli F, et al. Quantitative and qualitative profiles of circulating monocytes may help identifying tuberculosis infection and disease stages. PLoS One 2017; 12: e0171358.

Baldridge MT, King KY, Boles NC, et al. Quiescent haematopoietic stem cells are activated by IFN- $\gamma$ in response to chronic infection. Nature 2010; 465: 793-797.

Munn DH, Mellor AL. Indoleamine 2,3 dioxygenase and metabolic control of immune responses. Trends Immunol 2013; 34: 137-143.

Suzuki Y, Suda T, Asada K, et al. Serum indoleamine 2,3-dioxygenase activity predicts prognosis of pulmonary tuberculosis. Clin Vaccine Immunol 2012; 19: 436-442.

Adu-Gyamfi CG, Snyman T, Hoffmann CJ, et al. Plasma indoleamine 2, 3-dioxygenase, a biomarker for tuberculosis in human immunodeficiency virus-infected patients. Clin Infect Dis 2017; 65: 1356-1358.

Gautam US, Foreman TW, Bucsan AN, et al. In vivo inhibition of tryptophan catabolism reorganizes the tuberculoma and augments immune-mediated control of Mycobacterium tuberculosis. Proc Natl Acad Sci USA 2018; 115: E62-E71.

Dorhoi A, Du Plessis N. Monocytic myeloid-derived suppressor cells in chronic infections. Front Immunol 2018; 8: 1895.

O'Connor MA, Rastad JL, Green WR. The role of myeloid-derived suppressor cells in viral infection. Viral Immunol 2017; 30: 82-97.

du Plessis N, Loebenberg L, Kriel M, et al. Increased frequency of myeloid-derived suppressor cells during active tuberculosis and after recent Mycobacterium tuberculosis infection suppresses T-cell function. Am J Respir Crit Care Med 2013; 188: 724-732.

El Daker S, Sacchi A, Tempestilli M, et al. Granulocytic myeloid derived suppressor cells expansion during active pulmonary tuberculosis is associated with high nitric oxide plasma level. PLoS One 2015; 10: e0123772.

Dufour JH, Dziejman M, Liu MT, et al. IFN- $\gamma$-inducible protein 10 (IP-10; CXCL10)-deficient mice reveal a role for IP-10 in effector T cell generation and trafficking. J Immunol 2002; 168: 3195-3204.

Ferrero E, Biswas P, Vettoretto K, et al. Macrophages exposed to Mycobacterium tuberculosis release chemokines able to recruit selected leucocyte subpopulations: focus on $\gamma \delta$ cells. Immunology 2003; 108: 365-374.

Azzurri A, Sow OY, Amedei A, et al. IFN-gamma-inducible protein 10 and pentraxin 3 plasma levels are tools for monitoring inflammation and disease activity in Mycobacterium tuberculosis infection. Microbes Infect 2005; 7: 1-8. Ruhwald M, Bodmer T, Maier C, et al. Evaluating the potential of IP-10 and MCP-2 as biomarkers for the diagnosis of tuberculosis. Eur Respir J 2008; 32: 1607-1615.

Chegou NN, Sutherland JS, Malherbe S, et al. Diagnostic performance of a seven-marker serum protein biosignature for the diagnosis of active TB disease in African primary healthcare clinic attendees with signs and symptoms suggestive of TB. Thorax 2016; 71: 785-794.

Petrone L, Cannas A, Aloi F, et al. Blood or urine IP-10 cannot discriminate between active tuberculosis and respiratory diseases different from tuberculosis in children. Biomed Res Int 2015; 2015: 589471.

Petrone L, Cannas A, Vanini V, et al. Blood and urine inducible protein 10 as potential markers of disease activity. Int J Tuberc Lung Dis 2016; 20: 1554-1561.

Cannas A, Calvo L, Chiacchio T, et al. IP-10 detection in urine is associated with lung diseases. BMC Infect Dis 2010; 10: 333

9 Tenforde MW, Gupte N, Dowdy DW, et al. C-reactive protein (CRP), interferon gamma-inducible protein 10 (IP-10), and lipopolysaccharide (LPS) are associated with risk of tuberculosis after initiation of antiretroviral therapy in resource-limited settings. PLoS One 2015; 10: e0117424.

Vanini V, Petruccioli E, Gioia C, et al. IP-10 is an additional marker for tuberculosis (TB) detection in HIV-infected persons in a low-TB endemic country. J Infect 2012; 65: 49-59.

1 Santos VS, Goletti D, Kontogianni K, et al. Acute phase proteins and IP-10 as triage tests for the diagnosis of tuberculosis: a systematic review and meta-analysis. Clin Microbiol Infect 2018; in press [doi: 10.1016/j.cmi.2018. 07.017].

62 Miranda P, Gil-Santana L, Oliveira MG, et al. Sustained elevated levels of C-reactive protein and ferritin in pulmonary tuberculosis patients remaining culture positive upon treatment initiation. PLoS One 2017; 12: e0175278. 
163 Yoon C, Semitala FC, Atuhumuza E, et al. Point-of-care C-reactive protein-based tuberculosis screening for people living with HIV: a diagnostic accuracy study. Lancet Infect Dis 2017; 17: 1285-1292.

164 Lawn SD, Rudolph D, Wiktor S, et al. Tuberculosis (TB) and HIV infection are independently associated with elevated serum concentrations of tumour necrosis factor receptor type 1 and $\beta 2$-microglobulin, respectively. Clin Exp Immunol 2000; 122: 79-84.

165 Gieseg SP, Baxter-Parker G, Lindsay A. Neopterin, inflammation, and oxidative stress: what could we be missing? Antioxidants 2018; 7: in press [https://doi.org/10.3390/antiox7070080].

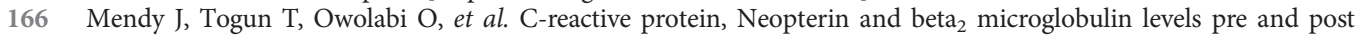
TB treatment in The Gambia. BMC Infect Dis 2016; 16: 115.

167 Tientcheu LD, Maertzdorf J, Weiner J, et al. Differential transcriptomic and metabolic profiles of M. africanumand M. tuberculosis-infected patients after, but not before, drug treatment. Genes Immun 2015; 16: 347-355.

168 Tientcheu LD, Haks MC, Agbla SC, et al. Host immune responses differ between M. africanum- and M. tuberculosis-infected patients following standard anti-tuberculosis treatment. PLoS Negl Trop Dis 2016; 10: e0004701.

169 Corstjens PL, de Dood CJ, van der Ploeg-van Schip JJ, et al. Lateral flow assay for simultaneous detection of cellular- and humoral immune responses. Clin Biochem 2011; 44: 1241-1246.

170 Pinto-Plata V, Casanova C, Müllerova $\mathrm{H}$, et al. Inflammatory and repair serum biomarker pattern: association to clinical outcomes in COPD. Respir Res 2012; 13: 71.

171 Richter B, Gwechenberger M, Socas A, et al. Time course of markers of tissue repair after ablation of atrial fibrillation and their relation to left atrial structural changes and clinical ablation outcome. Int J Cardiol 2011; 152: 231-236.

172 Diaz A, Bongiovanni B, D'Attilio L, et al. The clinical recovery of tuberculosis patients undergoing specific treatment is associated with changes in the immune and neuroendocrine responses. Pathog Dis 2017; 75: $10.1093 / \mathrm{femspd} / \mathrm{ftx} 087$

173 Deveci F, Akbulut HH, Turgut T, et al. Changes in serum cytokine levels in active tuberculosis with treatment. Mediators Inflamm 2005; 2005: 256-262.

174 Seddon J, Kasprowicz V, Walker NF, et al. Procollagen III N-terminal propeptide and desmosine are released by matrix destruction in pulmonary tuberculosis. J Infect Dis 2013; 208: 1571-1579.

175 Sigal GB, Segal MR, Mathew A, et al. Biomarkers of tuberculosis severity and treatment effect: a directed screen of 70 host markers in a randomized clinical trial. EBioMedicine 2017; 25: 112-121.

176 Ong CW, Elkington PT, Friedland JS. Tuberculosis, pulmonary cavitation, and matrix metalloproteinases. Am J Respir Crit Care Med 2014; 190: 9-18.

177 Berry MP, Graham CM, McNab FW, et al. An interferon-inducible neutrophil-driven blood transcriptional signature in human tuberculosis. Nature 2010; 466: 973-977.

178 Bloom CI, Graham CM, Berry MP, et al. Transcriptional blood signatures distinguish pulmonary tuberculosis, pulmonary sarcoidosis, pneumonias and lung cancers. PLoS One 2013; 8: e70630.

179 Kaforou M, Wright VJ, Levin M. Host RNA signatures for diagnostics: an example from paediatric tuberculosis in Africa. J Infect 2014; 69: Suppl. 1, S28-S31.

180 Maertzdorf J, Repsilber D, Parida SK, et al. Human gene expression profiles of susceptibility and resistance in tuberculosis. Genes Immun 2011; 12: 15-22.

181 Darboe F, Mbandi SK, Thompson EG, et al. Diagnostic performance of an optimized transcriptomic signature of risk of tuberculosis in cryopreserved peripheral blood mononuclear cells. Tuberculosis 2018; 108: 124-126.

182 Kaforou M, Wright VJ, Oni T, et al. Detection of tuberculosis in HIV-infected and -uninfected African adults using whole blood RNA expression signatures: a case-control study. PLoS Med 2013; 10: e1001538.

183 Cliff JM, Kaufmann SH, McShane $\mathrm{H}$, et al. The human immune response to tuberculosis and its treatment: a view from the blood. Immunol Rev 2015; 264: 88-102.

184 Bloom CI, Graham CM, Berry MP, et al. Detectable changes in the blood transcriptome are present after two weeks of antituberculosis therapy. PLoS One 2012; 7: e46191.

185 Thompson EG, Du Y, Malherbe ST, et al. Host blood RNA signatures predict the outcome of tuberculosis treatment. Tuberculosis 2017; 107: 48-58.

186 Cliff JM, Lee JS, Constantinou N, et al. Distinct phases of blood gene expression pattern through tuberculosis treatment reflect modulation of the humoral immune response. J Infect Dis 2013; 207: 18-29.

187 Baechler EC, Batliwalla FM, Karypis G, et al. Interferon-inducible gene expression signature in peripheral blood cells of patients with severe lupus. Proc Natl Acad Sci USA 2003; 100: 2610-2615.

188 Banchereau R, Cepika AM, Banchereau J, et al. Understanding human autoimmunity and autoinflammation through transcriptomics. Annu Rev Immunol 2017; 35: 337-370.

189 Bennett L, Palucka AK, Arce E, et al. Interferon and granulopoiesis signatures in systemic lupus erythematosus blood. J Exp Med 2003; 197: 711-723.

190 Zak DE, Penn-Nicholson A, Scriba TJ, et al. A blood RNA signature for tuberculosis disease risk: a prospective cohort study. Lancet 2016; 387: 2312-2322.

191 Bomanji JB, Gupta N, Gulati P, et al. Imaging in tuberculosis. Cold Spring Harb Perspect Med 2015; 5: doi: 10.1101/cshperspect.a017814

192 Sweeney TE, Braviak L, Tato CM, et al. Genome-wide expression for diagnosis of pulmonary tuberculosis: a multicohort analysis. Lancet Respir Med 2016; 4: 213-224.

193 Suliman S, Thompson E, Sutherland J, et al. Four-gene pan-African blood signature predicts progression to tuberculosis. Am J Respir Crit Care Med 2018; in press [https://doi.org/10.1164/rccm.201711-2340OC]

194 Duffy FJ, Thompson E, Downing K, et al. A serum circulating miRNA signature for short-term risk of progression to active tuberculosis among household contacts. Front Immunol 2018; 9: 661.

195 Riou C, Perez Peixoto B, Roberts L, et al. Effect of standard tuberculosis treatment on plasma cytokine levels in patients with active pulmonary tuberculosis. PLoS One 2012; 7: e36886.

196 Ferrian S, Manca C, Lubbe S, et al. A combination of baseline plasma immune markers can predict therapeutic response in multidrug resistant tuberculosis. PLoS One 2017; 12: e0176660.

197 Djoba Siawaya JF, Beyers N, van Helden P, et al. Differential cytokine secretion and early treatment response in patients with pulmonary tuberculosis. Clin Exp Immunol 2009; 156: 69-77. 
198 Fox W, Ellard GA, Mitchison DA. Studies on the treatment of tuberculosis undertaken by the British Medical Research Council tuberculosis units, 1946-1986, with relevant subsequent publications. Int J Tuberc Lung Dis 1999; 3: S231-S279.

199 Ottenhoff TH, Dass RH, Yang N, et al. Genome-wide expression profiling identifies type 1 interferon response pathways in active tuberculosis. PLoS One 2012; 7: e45839.

200 Honeyborne I, McHugh TD, Kuittinen I, et al. Profiling persistent tubercule bacilli from patient sputa during therapy predicts early drug efficacy. BMC Med 2016; 14: 68. 